\title{
THE GAP BETWEEN BELIEF AND ACTION: WHY IS IT THAT CHRISTIANS DO NOT PRACTISE WHAT THEY PREACH?
}

\author{
Louise Kretzschmar \\ University of South Africa
}

\section{Introduction}

The question raised by this title is, I believe, a crucial one because it reaches into the very heart of the Christian faith. It compels us to ask what it means to be a Christian and what the implications of such a commitment may be for our lives. It also raises questions about what constitutes the Christian faith itself and what the relationship is between belief and action, or theory and practice.

Before commencing with the content of my argument, it may be helpful for the readers of this volume if I briefly introduce myself. I was born on the East Rand and lived in the town of Benoni whilst growing up. There I attended a Dutch Reformed Church but received my education in English-speaking schools. After my conversion in my matric year, I joined a Baptist church. The next five years were spent studying at the University of the Witwatersrand. I then taught in a secondary school for nearly two years and thereafter completed a two year $\mathrm{M}$ Phil degree at Cambridge University. I returned home and taught at the University of Transkei for eight years. In 1991 I was appointed at UNISA where I am still employed. I am a member of Jubilee Baptist Church in Mamelodi which is a part of the Baptist Convention of South Africa.

In the paragraphs that follow, I endeavour to clarify what it means to be a Christian and what some the main causes are for the prevalence of a substantial credibility gap between what people claim to believe and how they actually behave.

\section{What is a Christian?}

As indicated by the title of this chapter, I have decided to address myself to the issue of the inconsistency between what is preached and what is practised. Is it not a fact that although South Africa has been regarded by many as a Christian country, much of our history has been decidedly unchristian? Violence, oppression, extortion, discrimination, structural evil, the abuse of power and the marginalisation of the poor and powerless have all being features of our history. Even at the present time, a marked lack of both personal and social morality is all too evident as witnessed in the many cases of murder, selfishness, rape, white collar theft, adultery, corruption, perjury, armed robbery, greed, sexual abuse, car hi-jackings, exploitation which are reported daily. In addition, although there are thousands of people who attend church on a regular basis, many of the sins just listed are also manifested in the lives of those who are within the church.

Against this background, attention must be drawn to a consideration of the term 'belief'. If one says 'I believe in God' or, more specifically, 'I believe in Jesus Christ', does this imply mere intellectual assent or genuine committed faith? For many people, belief implies merely intellectual acquiescence, that is, a theoretical affirmation of a certain doctrine without any intention to live in such a way as to give expression to this belief. Belief in the sense of committed faith, however, is an entirely different matter. Faith requires expression. One cannot speak of an inner conviction if there is no practical evidence of it. For this reason, Jesus could 
say 'so, then, you shall know them by their fruits. Not everyone who says to me, 'Lord, Lord' will enter the kingdom of heaven; but he who does the will of my Father who is in heaven' (Matt 7:20-21). Surely one of the reasons why the New Testament church was so vibrant was that it was overwhelmingly comprised of people who were actually committed. During this period, to express belief in Jesus Christ meant publicly confessing one's faith even at the risk of imprisonment and death (cf Acts 5:17-9:25). Arguably, in those periods of Church history when it cost something to declare that one was a Christian, the credibility of Christians was significantly higher than at other periods, when Christianity was both fashionable and comfortable.

A distinction also needs to be made between Christian faith and civil religion. A civil religion can be defined as the outer conformity of a nation with the externals of the faith without a corresponding inner conviction or a life commitment. Thus, religion is used to support and legitimate a particular social system for the benefit of a particular social group(s). Religion, in such an instance, serves the needs of civil society. ${ }^{(1)}$

Particularly in 'State' churches, such as the Lutheran church in Germany, or the Anglicans in England, church attendance may not be an indication of genuine faith, but rather conformity to the externals of the faith. Such persons may attend church out of habit or a sense of duty. In South Africa, the Dutch Reformed Church, whilst it was never officially the 'State' church, actually functioned in this way. Up until the 1990s, its ministers usually officiated at State functions, and many of those in the ruling elite were its members. For many Afrikaners going to Church on a Sunday was an accepted custom, it was expected of one and many conformed. Thus, the false impression may be given that church attendance necessarily implies Christian faith.

Closely linked with this notion of civil religion is the distinction between nominal and genuine Christian faith. A nominal believer is a believer in name only (from the Latin, nomen, a name). They may call themselves Christians, they may even run church camps, teach in the Sunday School, or serve in a leadership capacity, but they remain, at heart, pagans.

The point simply is that faith and action cannot be separated. Faith is not faith at all unless it is accompanied by commitment and action. This is revealed most clearly in the book of James: '... faith without works is dead' (James 2:26). Paul, too, linked faith and action, although this is often forgotten. Many people, strongly influenced by the Reformation affirmation of justification by faith 'by faith alone' are under the mistaken impression that one can claim to have genuine faith even if this faith issues in no action whatsoever. This is, however, a distortion of the teaching of the Reformers as well as of Paul's teaching from which this doctrine is derived. For Paul, one can only be saved by grace, not self effort, but faith must be followed by works (Eph 2:8-10). ${ }^{(2)}$

The key to Christian faith is both justification and sanctification or discipleship. To be a Christian is to be a disciple, that is to say, a follower of Jesus. What is needed is an ongoing encounter with God out of which grows joyful dedication and service. Not a reluctant, legalistic obedience but a living faith.

\section{Why is there a gap between what is preached and what is practised?}

A number of different reasons can be advanced in an attempt to explain why is it that Christian belief often does not issue in Christian action.

1 Cf Dunbar T Moodie (1975) The rise of Afrikanerdom: Power, Apartheid and Afrikaners Civil Religion (London: University of California Press).

2 See D Bonhoeffer's discussion of 'cheap grace' in the opening pages of The Cost of Discipleship (London: SCM). 


\section{A false separation between theological belief and ethical action}

The separation that is spoken of here relates to the debate surrounding 'orthodoxy' and 'orthopraxis'. Whilst some persons may stress 'right words/belief/doctrine' others may stress 'right action'. Thus, over the past 30-odd years a variety of theologians, many of whom are from the so-called 'third world', have asked the question: should the church be judged in terms of the purity and intellectual complexity of its doctrine or should it be judged in terms of the way in which it acts? What is essential to being a Christian: believing the right things or doing the right things?

There are many people who are convinced in their own minds that if they agree with the assertions of the various Creeds recited in many churches, this makes one a Christian.

However, what is the point of an entire congregation reciting their belief in, for example, the oneness and unity of the church if, in reality, that church is divided along racial lines? In South Africa, some churches were institutionally divided (eg the four Dutch Reformed Churches). Others were ostensibly one but, at a local parish level, were also racially divided (eg the Anglicans and Methodists). This continuing state of affairs has severe implications for the meaning and validity of the Creeds we recite and for the sacrament of communion. Does our disunity not bring dishonour on the celebration of the Lord's supper?

Similarly, churches in South Africa affirmed their belief in the Christian teaching that all human beings are created in God's image, that Christ died to save us, and that the Holy Spirit has been poured out upon us, and yet thousands of churches members went regularly to the 'whites only' elections and voted for the continued oppression of those who were their black brothers and sisters 'in the Lord'.

If our deeds do not match our words, we would do well to bear in mind some of the more chilling of Jesus' parables concerning the final separation of the 'sheep and the goats' (Matt 25:31-46). At a deeper level, Paul reminds us that action alone is worth nothing without love (1 Cor 13:1-13).

\section{Ignorance and a narrow theology}

There are those who, as a result of a very narrow theology, are largely ignorant of the content and implications of their faith. The all too common privatisation of the Christian faith is greatly to blame for this narrow perspective. Simply put, this means that the Christian faith is reduced to the private, personal concerns of individuals and separated from the needs and concerns of the wider society in which we live.

Rather than seeking to stress the Lordship of Christ over all of life, social and ecological included, Christ is seen as the Lord of 'my' life. Many South African Christians have thus busied themselves with personal discipleship, evangelism understood as the saving of souls, private worship, and church related activities such as bible studies, prayer groups, and Sunday worship. Politics was regarded as a 'dirty business' to be avoided by Christians. Thus, whilst many white Christians gave gifts of money for the alleviation of poverty, once one asked the question 'why are these people poor and why is it largely black people in South Africa who are poor?', then one was regarded as an agitator. If one persisted and mixed with such groups, one was branded as a 'kaffirboetie' or a communist.

A privatised faith is based on a dualism which separates reality into different spheres: the physical and the spiritual; the secular and the sacred; the public and the private; the saving of souls and social involvement. Personal religious transformation is encouraged but the application of religion to social structures is frowned upon.

A privatised approach also spiritualises the Gospel. Thus, in relation to passages such as 
Luke 4.18-20 or Matt 25.31-46, poverty and hunger, for example, are understood in terms of 'spiritual' needs only and not also in terms of physical or material needs. Such an approach forgets that as the Creator, God is concerned with both the body and the soul as well as all other aspects of life. This is exactly why the Old Testament prophets often spoke in a single breath of the need for personal and social morality (Is 1:16-20; Micah 6:6-8; and Zech 8:1417).

A third characteristic of a privatised approach is that it is a-contextual. This means that Christians sometimes separate their faith from the actual situation in which they live. At times Christians we seek to distance themselves from social evils such as child abuse, physical or emotional battering in marriages, the causes of teenage pregnancy, the causes of poverty, and the lack of land and housing.

The fourth characteristic of a privatised gospel is that of individualism. A distinction needs to be made here between the importance of the individual person and the overemphasis on the individual which results in the ignoring of the community or social aspects of our faith. Whilst it is true that only persons can be saved, it is not true that the implications of salvation in Christ are purely personal. We are saved in order to go out into the world to proclaim that salvation for persons, families and communities is to be found in Christ.

According to Kenneth Leech, Christian faith in the West has been severely paralysed by an excessive individualism. He argues that there should not be a separation between prayer and social change, between spirituality and social responsibility:

Self-knowledge, as all mystics insist, is the beginning of sanctity, but it is only the beginning. There must be a movement beyond the self to God, a real transformation of consciousness. Spiritual progress therefore involves a recognition of this false consciousness and of the false self, and Merton links this with individualism which has dominated western theology and politics for several hundred years' (Leech 1980: 83).

Whereas Jesus united prayer and healing, preaching and serving in his ministry, the church has all too often divided the two.

As a result, the Christian faith is understood in an overly cerebral way, as if to verbally affirm a Christian doctrine is equal to living out the Christian faith. The truth of the matter is that theological belief without ethical action is like trying to drive a car without an engine. Theological praxis, that is, the ongoing interaction between theological conviction and practical experience and action are crucial to the spiritual health and witness of the Christian Church.

At the risk of bringing down upon myself the ire of colleagues at theological faculties and bible colleges, I think that part of the problem is caused by the fact that ethics is often neglected at the expense of what is variously termed systematic theology, church doctrine or dogmatics. Christian ethics is often badly taught if taught at all. From a number of conversations I've had with a variety of ministers, it would appear that even when ethics was formally taught, insufficient time and discussion meant that theological students actually ended up attaining their qualification without having been adequately trained in this area. For the vast majority, it was only once they were in actual ministry in churches, that they had to begin to grapple with the range of ethical issues that arose in their own lives and the lives of the members of their congregations. If this is the experience of many ministers and pastors, can we expect that ordinary members should be adequately informed and able to deal with the very difficult questions that arise in our personal and social lives?

Furthermore, at certain theological training institutions, a much greater emphasis is given to personal rather than social ethics. Whilst it is true that it is difficult to separate the two, it is 
often the case that matters such as structural evil, social morality, the prophetic witness of the church, civil disobedience, group interest, and ideological manipulation not prominently featured in the syllabuses of theological training institutions. Thus, a restricted theology can only lead to a truncated faith and a deficient witness.

\section{The myth that personal conversion leads automatically to social involvement}

Many Evangelicals have long held the view that in order for the world to be renewed and transformed, individuals first had to be saved. This belief encompasses at one and the same time a profound truth and a dangerous assumption. The profound truth being that reconstruction must indeed begin with us, for it is true that transformed persons have the insight and passion that can transform unjust social structures. Nevertheless, it is a dangerous assumption that this is a process that occurs automatically. This was patently not the case in South Africa where the towns and countryside were literally dotted with churches and yet, the religious heresy and social injustice of the policy of Apartheid was maintained for over 40 years. $^{(3)}$ Even before 1948, colonialisation gave rise to widespread land appropriation, legalised injustice, economic exploitation, and cultural imperialism. Whilst within this context there were prophetic voices from within the church, they were distinctly in the minority. Furthermore, even when churches did protest, they seldom went beyond the articulation of verbal censure. ${ }^{(4)}$

Thus, whilst my own approach to theology is largely evangelical, with this naive form of evangelicalism I certainly do not agree. It is simply not the case that all saved individuals act in a moral fashion in all aspects of their lives nor that moral individuals go on to create a moral society. What, then, is wrong with this view?

To begin with, persons who adopt this approach understand conversion very narrowly. Conversion is not simply a reorientation in relation to 'spiritual' things, it implies a completely new approach to all the aspects of one's life, whether these relate to one's relationship to God, or to one' relationship to other human beings or social realities. Conversion and Christian commitment cannot be artificially separated from the wider spheres of socio-economic, political, cultural, environmental, and international affairs.

Secondly, they underemphasise the need for discipleship as an ongoing practical process. As already stated, this process of discipleship must include all the aspects of one's life. Christian faith can only be learnt in practice, it cannot simply be learnt out of a book, any more than one can read a book on prayer and then automatically become a man or woman of prayer. We are too cerebral in our approach; knowledge and intellectual assent is not all that is required from Christian, it is only an aspect of the whole. My colleague, Len Hulley, related this example provided by one of his teachers: 'we can't simply teach people the theory of music then expect them to play the piano'.

\section{Lack of exposure to different contexts}

Another reason that can be put forward to explain the gap between theory and practice is that of limited exposure. If Christians only mix with people from their own racial, class, cultural or gender group, they will probably lack both information and insight concerning the wider world. In effect, because their own world is so small, the questions with which they come to God are very restricted; little actual growth in terms of their personality or social awareness will occur.

3 See (eds) J de Gruchy \& C Villa-Vicencio, Apartheid is a Heresy (Cape Town: David Philip, 1983).

4 See C Villa-Vicencio, Trapped in Apartheid (Cape Town: David Philip, 1988). 
To put it another way, this is indicative of the fact that our social contexts have a notable influence on our perceptions of theology, ethics and role of the church in the wider society. No-one has a monopoly on 'the truth', rather, we are all affected to some extent by our context. To cite but two examples: Is it not true that Christians from various contexts reacted differently to the publication of the Kairos Document in 1985 and the elections in April 1994?

The most effective weapon in the hands of the Apartheid government was the withholding of knowledge (or the deliberate provision of 'disinformation'). By keeping those who were voting for them ignorant of what was really going on, the Afrikaner leaders could maintain the front of 'separate but equal' even though the reality was 'only partly separate but definitely unequal'. Many Afrikaans speaking people have said to me in recent years 'I didn't know'. How should one respond to such a claim? On the one hand, one could say 'there are none so deaf as those that don't want to hear'. For there were sources of contrary information, but many people simply turned a blind eye because they did not want to know what was going on because then they might feel compelled to do something about it. Consciously or unconsciously people knew that having a different view would bring them into conflict with their own culture and people and they were not prepared to pay this price. On the other hand, whilst many find it difficult to believe Afrikaners when they say 'we didn't know', it cannot be denied that the powers that be developed a very effective system of keeping people ignorant. For those that read only the sanctioned Afrikaans newspapers, mixed only with like-minded Afrikaners at school, home, church and in the work place, there was really little opportunity to see the situation in South Africa from another perspective. Similarly, many English speaking South Africans also lived in a very narrow and protected world. Whilst some of their leaders may have been more aware and outspoken, ordinary white members of the Anglican, Methodist, Catholic, Baptist, Presbyterian, etc churches lived in a white, privileged and ignorant world. They remained trapped within their narrow worlds.

\section{Personal Self Interest}

Any discussion of Christian commitment and the action that flows out of it must take the matter of personal self interest into account. As has already been indicated above, a self protective mechanism comes into play once people realise that Christian faith is costly. If acting in a way that is consistent with their beliefs threatens their security, self interest and comfort, they simply turn a blind eye.

There are a number of factors that could prevent individual believers from living out their faith in a full or complete way. For example, fear of failure or pain or the desire to avoid conflict may be determining factors. Even if persons feel that God is leading them in a particular direction, they may still choose to disobey. Jonah is a case in point. Thus, individuals may refuse to move beyond what is sometimes spoken of their 'comfort zones'. Such persons are seeking to be spectators rather than disciples. Can we expect anything other than a huge gap between stated belief and actual practice if the church is filled with what Dallas Willard has called 'undiscipled disciples'? (5) $^{(5)}$

\section{Group interests}

Personal self interest, though important, cannot account for every instance of unchristian behaviour. What is often left out of the equation is the powerful factor of group interest.

In this regard, Reinhold Niebuhr's book, Moral Man and Immoral Society, is extremely 
enlightening. Originally written in 1932, this classic book explains the all too prevalent phenomena of moral individuals who perform immoral social actions. Certain individuals, even though they may be morally upright persons in terms of their individual and family lives, once they form part of a social group, may protect the interests of that social group in a basically immoral way. They fail to apply their personal morality to social affairs because they fear (consciously or unconsciously) that this will threaten the social interests of that group. Reinhold Niebuhr put it like this:

As individuals, men believe that they ought to love and serve each other and establish justice between each other. As racial, economic and national groups they take for themselves whatever their power can command (Niebuhr 1932/1960:9).

Thus, white South Africans may have been kind, even generous, towards their servants without asking the deeper question as to why blacks were servants and whites were rulers. White Christians may have given generously to evangelistic work, mission hospitals and drought relief, but did they ask why they were in a position to give whilst others were generally on the receiving end? Did they question why blacks were required to carry passes in the land of their birth? That they were restricted in a host of different ways including where they could work, live, operate businesses, attend school, or engaging in farming? They only occasionally opened their churches to blacks during funerals or to listen to black choirs, but they did not offer their pulpits to black preachers or their hearts to the criticisms of black Christian leaders.

According to Reinhold Niebuhr, then, the powerful and the rich seek to maintain their positions and only give them up when compelled to do so. For this reason, a emphasis on personal morality does not ensure the removal of social immorality or injustice. Persons may be moral in terms of personal relations, but be immoral in terms of social structures because they are protecting the perceived interests of their group. Whilst they claim to put Christ first, in reality, the interests of their social group are primary.

Within the current situation in South Africa, a whole new set of power relations is developing. Here, too, the factor of group interests operates in a significant way. It will be instructive to note to what extent the new black elite promote their own class interests at the expense of the black masses from which they have so recently emerged.

In this regard the whole matter of class analysis is significant. The point is simply that different classes perceive religion differently and it performs a variety of social functions depending on the variables operative in that situation. At the risk of oversimplification, the ruling classes use religion to impose control and conformity, the middle classes pursue individualistic goals (often at the expense of social justice for the under classes) and the under classes seek social change and transformation. Each, then, selectively uses the bible and certain Christian doctrines to promote its own interests.

What is meant by the phrase 'the social function of religion'? It is a common feature of the sociology of religion (sociology is the systematic study of human social reality) to try to determine the role that religion plays in society. Whilst sociologists disagree as to what these functions are, a distinction is often made between the manifest and latent functions of religion. Manifest functions are those functions identified by the adherents themselves (eg the need for forgiveness, salvation, and meaning in life) whilst the latent functions are those identified by sociologists (eg social cohesion, social control or social change). In order to understand the way in which religion functions or operates, it is, I believe, important to stress both the manifest and the latent functions of religion ${ }^{(6)}$. In terms of the ruling classes, the views of Karl

6 Three classic models that can be identified within the sociology of religion are those of Emile Durkheim, Karl 
Marx are important. Whilst many Christians have been critical of Marx's own life and many of his ideas, his analysis of the social function of religion cannot be dismissed. According to Marx, the function of religion was primarily that of social control. Marx regarded religion as a form of false consciousness which provided the ruling classes with a legitimation of their powerful social position. Religion further gave the oppressed masses a social narcotic that transmuted their material expectations into a hope of a better heavenly experience, compensated them for their miserable existence, and caused them to passively accept their lot in life.

In South Africa, certain forms of Christianity did perform the function of legitimating the position of the powerful whilst it encouraged the poor and oppressed to passively accept the crumbs that fell from the master's table. By insisting that 'religion must not be mixed with politics' (whilst our former rulers quietly used religion to justify their own politics) the government in South Africa effectively disempowered the churches. By withdrawing from the political realm, many Christians supported the status quo by default. Because they were not part of the solution, they were indeed part of the problem.

Richard H Niebuhr (Reinhold's brother) wrote about the way in which religion is understood and practised in middle class contexts. Basically, it is perceived in an individualistic way since the middle classes have attained a position of relative economic abundance. Because their needs are personal and family orientated instead of being orientated towards social survival, they understand sin and salvation in individualistic terms:

Sin is not so much a state of soul as a deed or a characteristic: it is not so much the evil with which the whole social life and structure is infected as it is the personal failure of the individual (Richard Niebuhr 1929/1957:85).

Because sin and salvation are perceived in this individualistic way, believers are encouraged to pursue their religious convictions in terms of the pursuit of personal holiness and effort. Because they are socially well provided for, their religious passion does not issue in a concern for social justice. Especially not when they mix only with persons from their own social group.

What then of the so-called working classes or under classes? In this instance, the work of Max Weber can thrown some light onto the situation. Weber, whilst he admitted that religion sometimes functioned in the way identified by Karl Marx, argued that religion could also function as an agent of social change. It can empower individuals and groups to progress up the socio-economic ladder. ${ }^{(7)}$ In certain circumstances, led by charismatic leaders from the marginalised groups within society, religion could perform a prophetic and subversive function. Instead of propping up the status quo it could undermine it and initiate a creative process of social transformation. ${ }^{(8)}$

Arguably, this is the way in which certain religious groups functioned in South Africa. The rise of African Theology, Black Theology and Liberation Theology ${ }^{(9)}$ in the late 1960's in South Africa encouraged a religious critique of the system. As a consequence a number of books emerged which were intensely critical of all the facets of Apartheid. ${ }^{(10)}$ Groups such as

Marx and Max Weber. Cf G Baum, Religion and Alienation (New York: Paulist Press, 1975); (eds) R Bocock and $\mathrm{K}$ Thompson Religion and Ideology (Manchester: University Press, 1985).

7 Weber, The Protestant Ethic and the Spirit of Capitalism (London: Unwin Hyman, 1930).

8 See C Villa-Vicencio, Trapped in Apartheid, pp 183-189.

9 In South Africa, Feminist Liberation Theology only began to exercise a marked influence in the 1980's.

10 Eg Itumeleng Mosala \& Buti Thagale, The unquestionable right to be free (Johannesburg: Skotaville, 1986) \& Hammering Swords into Ploughshares: Essays in Honour of Archbishop Mpilo Desmond Tutu (Johannesburg: 
the University Christian Movement (UCM), The South African Student's Organisation (SASO), South African Council of Churches (SACC) and the Institute of Contextual Theology (ICT) popularised these theological critiques of the South African system, conscientised their members, and mobilised thousands of people to protest in a variety of forms including mass marches. Within a variety of churches, both black and white, certain individuals and groups exercised a prophetic function. Often ignored, despised or vilified, such persons and groups were expressive of Weber's stress that religion can function as a critical and renewing social force.

In short, the drive of social groups to seek to use religion for their own ends cannot be denied. Nor can the issue of whether these interests are compatible with the Gospel of Jesus Christ be ignored. The abuse of religion by social groups can, thus, contribute to the credibility gap that is under discussion in this chapter.

\section{Spiritual Immaturity}

The final reason I wish to offer is that of spiritual immaturity. Here the word 'spiritual' refers not to some isolated devotional dimension but to the whole of a person's life as lived in obedience to and empowered by the Spirit of God.

In the book, God of Surprises, Gerard Hughes speaks of the three stages of Christian development described by von Hugel which correspond to childhood, adolescence and adulthood.

We begin our Christian walk, he says, with the institutional stage which stresses acceptance of the beliefs of the church and obedience to the authority of the church.

The second stage is called the critical stage because though we remain faithful Christians, we begin to criticise and ask questions. We no longer do things on the basis of the Minister or the Moderator's instructions, we want to know 'why'? This critical stage employs the rational aspect of our faith to a great extent. It is a valuable stage because it means that those in authority have to be accountable.

The third stage is called the mystical stage because it involves a deeper walk with God than that which has been experienced before. It is an adult stage because it requires a degree of Christian maturity and it involves a passionate love for God and a desire to know and serve God from the heart.

The important thing to remember is that we never simply progress from one stage to another, leaving the previous stage behind. As we move on to the next stage, we ADD the concerns and commitment of the next stage to the earlier stage(s). Thus, even when we are critical of the church we remain loyal to it. We recognise that the church is full of faults because we are in it! We constitute a prophetic spirit of critical loyalty within the church, seeking to change and improve it from the inside. Similarly, when we are ready for the mystical stage, we do not abandon the institution nor the use of our minds as a God-given critical instrument, rather we add to obedience and analysis a deeper partnership with God.

If Hughes's model is valid, at least two issues arise. The first is to discover whether Christian leaders have progressed through these three stages. For instance, do leaders expect blind obedience? If they have not progressed beyond the institutional stage they will feel uncomfortable with those who are either critical or are seeking a deeper experience of God and a more meaningful and effective application of their faith to the wider reality around them.

The second issue relates to the individual responsibility of the believers. Have they sought 
to grow in their experience of God and their attempts to live out their faith at home, work and in the wider community? Or have they clung to their 'comfort zones' and refused to act in accordance with what they say they believe?

Because many churches still appear to be in the institutional stage, we need to take note of the psychological effects of authoritarian religion. In Religion and Alienation, Gregory Baum argues that authoritarian religion is characterised by control. It makes people dependent, passive and uncritical. Such believers '... feel safe only in social, political and ecclesiastical institutions where few decisions are demanded of them' (1975:93). Women, in particular, because they are seldom encouraged to develop all their gifts and potential (lest it threaten the male power structure) often remain dependent, passive and uncritical. ${ }^{(11)}$

If believers, both men and women, seek to develop a mature Christian spirituality, they need to ask whether Hughes and Baum's analyses are valid and, if so, what the implications are for their personal life and the teaching and activities of their church. Secondly, a much wider understanding of Christian discipleship and ministry need to be developed. The need is to move beyond a circumscribed spirituality to a more biblical and comprehensive spirituality.

\section{Summary}

To sum up, individual persons need to establish whether their faith amounts to a genuine commitment or whether it merely implies intellectual assent. Furthermore, the false separation between theological belief and ethical action needs to be overcome. Theological ignorance or narrowness, together with the myth that personal conversion leads automatically to social involvement, must simply be abandoned. Both personal and group self interests need to be identified and honestly faced if we are to uncover the deeper motivations for our lack of Christian character and action in both our personal and social lives.

With respect to spiritual maturity, we need to establish the degree to which we have grown as disciples. Whilst such an appraisal is complex, it cannot be avoided. Unless we know who we are in a deep and profound way, no real growth is possible. We also need to recognise that social paralysis is sometimes the result of feeling overwhelmed by the enormous needs of the world. Both in terms of the people one meets on a daily basis, and in terms of the exposure one receives from the media (whether this be radio, television or the newspapers), all of us are daily confronted with killings, divorce, corruption, misery, war, trauma, emotional and physical abuse, environmental destruction and many more. The effect of exposure to this vast range of disasters and needs may have the effect of paralysing even those persons who do wish to engage in Christian service and ministry. In this regard, the solution is not to seek to respond to everything in a superficial way. Instead, I suggest, that we can seek (before God and together with the Christian community) to isolate and confess the reasons for our own reluctance and disobedience in the past, to identify our own gifts and interests, to seek to hear the call of God in relation to our own context and gifts, and then to go on to seek to enter into a process of obedience to God by means of acting in terms of the specifics of what we are being called to do. In this way, I submit, the gap between belief and action can be overcome and the credibility of the Christian Church can be significantly improved.

11 See (eds) D Ackermann, et al (1991), Women hold up half the Sky and L Kretzschmar (1995) 'Women and Culture: Ecclesial and Cultural Transformation' in (eds) C Villa-Vicencio \& C Niehaus, Many Cultures, One Nation, pp 90-104. 


\section{BIBLIOGRAPHY}

Ackerman, Denise, et al (eds) (1991) Women hold up Half the Sky: Women in the Church in Southern Africa (Pietermaritzburg: Cluster).

Baum, Gregory (1975) Religion and Alienation: A theological reading of Sociology (New York: Paulist Press).

Beesing, M, Nogosek, Robert J and O' Leary, Patrick, H (1984) The Enneagram: A Journey of Self Discovery (Denville, NJ: Dimension Books).

de Gruchy, John (1986) Theology and Ministry in Context and Crisis: A South African Perspective (London: Collins).

de Gruchy, John (1986) Cry Justice: Prayers, Meditations and Readings from South Africa (London: Collins).

Foster, Richard J \& Smith, James B (1990) Devotional Classics: Selected Readings for individuals and groups (London: Hodder and Stoughton).

Foster, Richard J (1978) Celebration of Discipline: The Path to Spiritual Growth (London: Hodder and Stoughton).

Hoffmeister, D \& Kretzschmar L (eds) (1995) Towards a Afrocentric, Holistic and Participatory understanding of the Gospel of Jesus Christ (Proceedings of the 1995 Winter School of Theology), (Johannesburg: Baptist Convention of South Africa).

Hudson, Trevor (1995) Signposts to Spirituality: Towards a closer walk with God (Cape Town: Struik).

Hughes, Gerard (1985) God of Surprises (London: Darton, Longman \& Todd).

Hulley, L H (1988) To Be and To Do (Pretoria: UNISA).

Kretzschmar, Louise (1994) 'Ethics in a theological context' in (eds) C Villa-Vicencio \& John de Gruchy, Doing Ethics in Context (Cape Town: David Philip).

Kretzschmar, Louise (1995) 'Women and Culture: Ecclesial and Cultural Transformation' in (eds) C Villa-Vicencio \& C Niehaus, Many Cultures, One Nation (Cape Town: Human \& Rousseau) pp 90-104.

Kretzschmar, Louise (1992)' The Privatization of the Christian Faith amongst South African Baptists: with particular reference to its nature, extent, causes and consequences' (University of Cape Town: unpublished $\mathrm{PhD}$ ).

Leech, Kenneth (1980) True Prayer: An Introduction to Christian Spirituality (London: Sheldon Press).

Niebuhr, Reinhold (1932/1960) Moral Man and Immoral Society (New York: Scribners).

Niebuhr, Richard H (1929/1957) The Social Sources of Denominationalism (New York: New American Library).

Nouwen, Henri J (1975) Reaching Out: Three movements of the Spiritual Life (London: Fount).

Villa-Vicencio, Charles (1988) Trapped in Apartheid (Cape Town: David Philip). 